\title{
RATIONALITY ASSESSMENT OF ZINC FORMULATIONS AVAILABLE IN INDIA
}

\author{
KRISHNAN VENGADARAGAVA CHARY, RITHU BHASKARAN
}

Department of Pharmacology, Saveetha Medical College, Chennai, II MBBS, Saveetha Medical College, Chennai

Email: drvkresearch@gmail.com

Received: 14 Apr 2017 Revised and Accepted: 30 Jun 2017

\begin{abstract}
Objective: To critically analyze the essentiality and irrational zinc preparations available in Indian market.

Methods: This was conducted as cross-sectional analysis by department of pharmacology of our tertiary care hospital between June and December 2016. Data regarding various formulations of zinc were retrieved from current index of medical sciences and drug India database. Rationality assessment was done using prescribed guidelines and approved formulations of zinc by Central drug standard control organisation. Essentiality was checked using National list of essential medicine India, 2013 and latest version of WHO list essential medicine bulletin. Dosage regulation was assessed using Indian pharmacopeia guidelines, National institute of nutrition, India recommendation and upper daily intake toxicity intake, United States of America (USA)
\end{abstract}

Results: Our study results showed wide variation in the number of zinc preparation. Total number of formulation available in the market is 335 Among zinc preparation, the preparation that contains $20 \mathrm{mg}$ of zinc as recommended by various guidelines is 10 in number. About 325 preparations of zinc are added with one or more nutraceuticals. None of these fixed dose combination of zinc containing preparation is recommended as essential fixed regimen.

Conclusion: Zinc has lot of relevance in treating recurrent diarrhoeal illness, especially in paediatric cases; however legal, regulatory and educational measures should be followed to curtail all the irrational zinc prescription development, promotion, marketing and prescription.

Keywords: Zinc preparations, Irrational prescribing, Fixed dose combinations, Nutraceuticals

(C) 2017 The Authors. Published by Innovare Academic Sciences Pvt Ltd. This is an open access article under the CC BY license (http://creativecommons.org/licenses/by/4.0/) DOI: http://dx.doi.org/10.22159/ijpps.2017v9i8.19178

\section{INTRODUCTION}

Since 1960s, role of zinc in health is well established. Recently, more evidence based recommendations has been made to emphasise the significance iron for normal homeostasis. Zinc is one of the essential mineral required by the body; it exhibits various pleiotropic effects and pivotal for normal functioning of various physiological system and effects. Zinc is a cofactor/co-activator of many biological enzyme involved in deoxyribo nucleic acid synthesis (DNA), functioning of male reproductive system including spermatogenesis. It is also critical for embryonic development of the foetus. Biological role of zinc in pathogenesis of diabetes mellitus and chronic bronchial asthma are currently under evaluation.

Zinc deficiency is usually encountered in malnutrition, among chronic alcoholics, patients with sickle cell anaemia etc. Nutritional antagonism can also be seen where staple food is cereals with high phytates content [1-3].

Therapeutic uses of zinc is well established in two conditions, Wilson disease and paediatric diarrhoeal illness. There are plenty of epidemiologic studies that shows zinc levels suboptimal in children with malnutrition, prone for recurrent diarrhoea and vice-versa. In a report of by World Health organisation in 2003, detailed description of morbidity and mortality prevention of diarrhoeal illness among children by effectiveness of zinc is provided. Role of zinc in diarrhoeal illness when used approximately is evident by other parmacoepidemiologic studies as well. However, zinc should be administered as per dosage recommendation given vide infra in discussion and should be curtailed in adding with other nutraceuticals which is neither effective nor safe as zinc has its own adverse effects $[4,5]$.

Hence this observational study was conducted to analyze the currently available rational and essential zinc formulation in our country.

\section{MATERIALS AND METHODS}

Methods

This was conducted as cross-sectional analysis by department of pharmacology of our tertiary care hospital between June and December 2016. Data regarding various formulations of zinc were retrieved from current index of medical sciences and drug India database. Rationality assessment was done using prescribed guidelines and approved formulations of zinc by Central drug standard control organisation. Essentiality was checked using national list of essential medicine India, 2013 and latest version of WHO list essential medicine bulletin. Dosage regulation was assessed using Indian pharmacopeia guidelines, National institute of nutrition, India recommendation and upper daily intake toxicity intake, United States of America (USA)

Data entered in MS world excel and descriptive statistics employed used to infer the database.

Table 1: Number of zinc preparations and combinations

\begin{tabular}{ll} 
Zinc preparations and combinations & Number \\
\hline Total No. of zinc & 335 \\
Total No. of zinc with $20 \mathrm{mg}$ & 10 \\
Total No. of zinc with calcium & 127 \\
Total No. of zinc with iron & 147 \\
Total No. of zinc with B complex & 214 \\
Lowest dose & $30 \mathrm{mcg}$ \\
Highest dose & $104.53 \mathrm{mg}$ \\
\hline
\end{tabular}


Table 2: Dosages of zinc preparations and combinations available in market

\begin{tabular}{|c|c|}
\hline Zinc dosages in various formulations & Number of formulations \\
\hline $4 \mathrm{mg}$ & 20 \\
\hline $17.6 \mathrm{mg}$ & 1 \\
\hline $11 \mathrm{mg}$ & 8 \\
\hline $7.5 \mathrm{mg}$ & 30 \\
\hline $5 \mathrm{mg}$ & 7 \\
\hline $15 \mathrm{mg}$ & 35 \\
\hline $1 \mathrm{mg}$ & 7 \\
\hline $54.93 \mathrm{mg}$ & 3 \\
\hline $3 \mathrm{mg}$ & 12 \\
\hline $1.1 \mathrm{mg}$ & 1 \\
\hline $80 \mathrm{mg}$ & 1 \\
\hline $40 \mathrm{mg}$ & 3 \\
\hline $20 \mathrm{mg}$ & 10 \\
\hline $50 \mathrm{mg}$ & 7 \\
\hline $1.25 \mathrm{mg}$ & 3 \\
\hline $25 \mathrm{mg}$ & 6 \\
\hline $22.5 \mathrm{mg}$ & 21 \\
\hline $28.7 \mathrm{mg}$ & 1 \\
\hline $2.2 \mathrm{mg}$ & 1 \\
\hline $10 \mathrm{mg}$ & 20 \\
\hline $2 \mathrm{mg}$ & 6 \\
\hline $0.6 \mathrm{mg}$ & 1 \\
\hline $63 \mathrm{mg}$ & 3 \\
\hline $8 \mathrm{mg}$ & 2 \\
\hline $61.8 \mathrm{mg}$ & 49 \\
\hline $14.7 \mathrm{mg}$ & 2 \\
\hline $6.97 \mathrm{mg}$ & 1 \\
\hline $3.34 \mathrm{mg}$ & 1 \\
\hline $70 \mathrm{mg}$ & 1 \\
\hline $1.5 \mathrm{mg}$ & 1 \\
\hline $27.5 \mathrm{mg}$ & 5 \\
\hline $75 \mathrm{mg}$ & 2 \\
\hline $75 \mathrm{mcg}$ & 1 \\
\hline $2.75 \mathrm{mg}$ & 1 \\
\hline $24.89 \mathrm{mg}$ & 1 \\
\hline $65 \mathrm{mg}$ & 1 \\
\hline $49 \mathrm{mg}$ & 1 \\
\hline $12 \mathrm{mg}$ & 1 \\
\hline $15.5 \mathrm{mg}$ & 1 \\
\hline $6.97 \mathrm{mg}$ & 1 \\
\hline $9.23 \mathrm{mg}$ & 1 \\
\hline $22.22 \mathrm{mg}$ & 7 \\
\hline $32.98 \mathrm{mg}$ & 1 \\
\hline $41.2 \mathrm{mg}$ & 4 \\
\hline $13.3 \mathrm{mg}$ & 9 \\
\hline $1.05 \mathrm{mg}$ & 1 \\
\hline $44.4 \mathrm{mg}$ & 2 \\
\hline $33 \mathrm{mg}$ & 6 \\
\hline $7 \mathrm{mg}$ & 3 \\
\hline $10.98 \mathrm{mg}$ & 1 \\
\hline $60 \mathrm{mg}$ & 2 \\
\hline $30 \mathrm{mg}$ & 2 \\
\hline $31 \mathrm{mg}$ & 1 \\
\hline $55 \mathrm{mg}$ & 2 \\
\hline $2.5 \mathrm{mg}$ & 2 \\
\hline $18 \mathrm{mg}$ & 1 \\
\hline $40 \mathrm{mg}$ & 2 \\
\hline $19 \mathrm{mg}$ & 1 \\
\hline $41.4 \mathrm{mg}$ & 1 \\
\hline $35 \mathrm{mg}$ & 1 \\
\hline $61.5 \mathrm{mg}$ & 1 \\
\hline $20.6 \mathrm{mg}$ & 1 \\
\hline $19 \mathrm{mg}$ & 1 \\
\hline $5.5 \mathrm{mg}$ & 1 \\
\hline 66 mg & 1 \\
\hline $30 \mathrm{mcg}$ & 2 \\
\hline $104.53 \mathrm{mg}$ & 1 \\
\hline
\end{tabular}




\section{RESULTS}

Our study results showed wide variation in the number of zinc preparation. Total number of formulation avalaible in the market is 335. Among zinc preparation, the preparation that contains $20 \mathrm{mg}$ of zinc as recommended by various guidelines is 10 in number. About 325 preparations of zinc are added with one or more nutraceuticals. None of these fixed dose combination of zinc containing preparation is recommended as essential fixed regimen by national list list essential medicines for adults and children, India and essential list of World health organization.

Detailed list zinc formulations and their dosage subscription is given in table 1 and table 2 .

\section{DISCUSSION}

Diarrhoeal illness is a common entity and a major killer among under five age group children which is easily treatable by rehydration and antibiotics, if necessary. Role of zinc is well established and it has its own evidence based recommendation; however irrational zinc supplementation is unacceptable owing to suboptimal benefits and cumulative toxicity [6].

Many irrational nutraceutical preparations contain zinc in the quantity which is not as per recommendation to treat diarrhoea effectively. As depicted in results zinc lesser than $20 \mathrm{mg} / \mathrm{d}$ is included in more than eighty percent for formulations. Formulations that contain less than $20 \mathrm{mg} / \mathrm{d}$ and less than $10 \mathrm{mg} / \mathrm{d}$ for infants do not confer any benefits in terms of reduction natural course of diarrheal illness.

Zinc is also added irrationally in multi-vitamin preparations and that are commonly available over the counter. These preparations apparently misused by the consumers and also prescribed without rationale by the physicians. Though acute toxicity of zinc is rarely encountered, it must be remembered zinc is not entirely safe. Chronic ingestion of zinc can result in copper depletion, anaemia, respiratory distress and drug fever $[7,8]$.

None of the fixed dose combinations of zinc is recommended in national list of essential medicines and WHO list of essential medicines. Such combinations are irrational, not cost effective and its sale can be considered illegal. Nutraceuticals, in general considered safe and their ill effects are unrecognised in our scenario. In diarrhoeal illness with or without symptoms like fever zinc currently not prescribed as per their recommendations which must be emphasized from the level of primary health care [9-11].

Main reason for such free flowing fixed FDCs are reluctant legal measures, unawareness of public system and under diagnosing and reporting of nutraceuticals toxicity which is done meticulously is west. India banned 334 irrational fixed dose combinations of many drugs but unfortunately none of the sole multi-vitamin preparations were included in list.

Suggestions to overcome this hurdle include discrepancy between drug approval policy between central and regional entity must be resolved. Single window must be adopted for drug licensing. Periodic surveillance must be carried out to screen irrational preparations and for content adequacy analysis of approved preparation. Over the counter sale of drugs must be discouraged, reluctant approach to nutraceuticals use by physicians and misuse by consumer must be curtailed by legal and educational measures [12-15].

\section{CONCLUSION}

Zinc has lot of relevance in treating recurrent diarrhoeal illness, especially in paediatric cases; however legal, regulatory and educational measures should be followed to curtail all the irrational zinc prescription development, promotion, marketing and prescription. Zinc formulation contains $20 \mathrm{mg} / \mathrm{d}$ should be prescribe for paediatric cases with diarrhoeal illness; irrational combinations should be curtailed.

\section{LIMITATION}

This was done as cross sectional study and also region wise variation in zinc dosage formulations were not analyzed. Periodic assessment would be required to update in this regard.

\section{AUTHOR CONTRIBUTION}

\begin{tabular}{lll}
\hline & Contributor 1 & Contributor 2 \\
\hline Concepts & $\sqrt{ }$ & $\sqrt{ }$ \\
Definition of intellectual content & $\sqrt{ }$ & $\sqrt{ }$ \\
Literature search & $\sqrt{ }$ & $\sqrt{ }$ \\
Data acquisition & $\sqrt{ }$ & $\sqrt{ }$ \\
Manuscript preparation & $\sqrt{ }$ & $\sqrt{ }$ \\
Manuscript editing & & $\sqrt{ }$ \\
Manuscript review & & $\sqrt{ }$ \\
Guarantor & & $\sqrt{ }$ \\
References & & \\
\hline
\end{tabular}

\section{CONFLICT OF INTERESTS}

\section{Declared none}

\section{REFERENCES}

1. Roohani N, Hurrell R, Kelishadi R, Schulin R. Zinc and its importance for human health: an integrative review. J Res Med Sci 2013;18:144-57.

2. Plum LM, Rink L, Haase H. The essential toxin: impact of zinc on human health. Int J Environ Res Public Health 2010;7:1342-65.

3. Inoue $\mathrm{K}, \mathrm{O}^{\prime}$ Bryant Z, Xiong ZG. Zinc-permeable ion channels: effects on intracellular zinc dynamics and potential physiological/pathophysiological significance. Curr Med Chem 2015;22:1248-57.

4. World Health Organization. The World Health Report 2007-a Safer Future: Global Public Health Security in the 21st Century. Geneva: WHO; 2007.

5. Bryce J, Boschi-Pinto C, Shibuya K. WHO estimates of the causes of death in children. Lancet 2005;365:1147-52.

6. Kosek M, Bern C, Guerrant RL. The global burden of diarrhoeal disease, as estimated from studies published between 1992 and 2000. Bull World Health Organization 2003;81:197-204.

7. GJ Fosmire. Zinc toxicity. Am J Clin Nutr 1990;51:225-7.

8. Prasad AS. Zinc in human health: effect of zinc on immune cells. Mol Med 2008;14:353-7.

9. Babu TA. The ideal zinc preparation in the management of acute diarrhoea in children. Indian J Pharmacol 2013;45:539.

10. J Thirunavukkarsau, V Krishnan. Analysis of prescription pattern of general practitioners at different pharmacies in avadi-Chennai. Int J Pharm BioSci 2015;6:1048-51.

11. V Krishnan, Prakash Murugaiah, Aruna Maria Bachmann. Are we too reluctant about irrational nutraceutical combinations? Int J Basic Clin Pharmacol 2016;5:2585-8.

12. Jadav SP, Parmar DM. Critical appraisal of irrational drug combinations: A call for awareness in undergraduate medical students. J Pharmacol Pharmacother 2011;2:45-8.

13. Gupta YK, Ramachandran SS. Fixed dose drug combinations: issues and challenges in India. Indian J Pharmacol 2016;48:347-9.

14. Sharma K, Sharma A, Singh V, Pilania D, Sharma YK. Irrational fixed dose combinations and need for intervention: understanding of dental clinicians and residents. J Clin Diagnostic Res 2014;8:49-52.

15. N Venkateswaramurthy, R Murali, R Sampath Kumar. The study of drug utilization pattern in pediatric patients. Int J Pharm Pharm Sci 2013;3:140-4.

\section{How to cite this article}

- Krishnan Vengadaragava Chary, Rithu Bhaskaran. Rationality assessment of zinc formulations available in India. Int J Pharm Pharm Sci 2017;9(8):200-202. 